- Laboratorium: Russian Review of Social Research. 2019. 11(1):186-190

\title{
Mischa Gabowitsch
}

\section{Nikolay Koposov. Memory Laws, Memory Wars: The Politics of the Past in Europe and Russia. Cambridge: Cambridge University Press, 2018. 328 pages. ISBN 978- 1-108-41016-8.}

\begin{abstract}
Mischa Gabowitsch is a research fellow at the Einstein Forum in Potsdam, Germany, and was the founding editor-in-chief of Laboratorium. Address for correspondence: Einstein Forum, Am Neuen Markt 7, Potsdam, 14467, Germany. mischa.gabowitsch@einsteinforum.de.
\end{abstract}

Even for a frequent reviewer of scholarly publications, it is a rare pleasure to be able to write about a book that one knows instantly will become a field-defining classic. Nikolay Koposov's study of memory laws is such a case. Its sweeping geographic scope, impressively broad and nuanced coverage of sources and secondary literature, and pluridisciplinary analytical depth will surely make this the main reference work on European memory laws and their historical and political context for years to come. Based in part on his earlier Russian-language book on memory politics (Koposov 2011), this new study expands his perspective far beyond the Russian case, providing a beneficial distance from the fray that gave rise to the previous book.

Koposov approaches the topic as a historian and treats the advent of memory laws as a phenomenon in need of historical explanation and contextualization. A recent one at that: the cascade of Holocaust denial laws started as a trickle in the 1980s (in West Germany and Israel) and swelled to torrential proportions following the hotly debated French Gayssot Act of 1990, which Koposov describes as "prototypical" (p. 8). Rather than a single type of legislation, the term in fact covers a complex of different, though related, phenomena. In the broadest sense, it includes laws that define state symbols, create museums, or grant amnesties or benefits to participants in certain historical events. As the author makes clear in his introduction, "the notion can be used both in a broad sense encompassing all laws that regulate collective representations of the past and in the narrow sense of prohibitions on Holocaust denial and other similar legislation" (p. 2), the latter being the "hard core" of memory laws that is the main focus of the book.

This double definition introduces a first distinction that is fundamental to Koposov's analysis: the diachronic one between modern memory laws, properly speaking, and their legislative antecedents-most importantly Western laws banning fascist movements and symbols starting in the 1940s, as well as the first deCommunization laws in early 1990s Eastern Europe. In Western Europe, Koposov argues, several tendencies came together to produce a "Holocaust-and-heritage model of ... historical consciousness" (p. 82). In the postwar decades historians developed an increased focus on the oppressed and eventually moved from a supposedly objective social history to an interest in multiple subjectivities. This paved the way for a democratization, in the form of a "memory boom," that stripped his- 
torians of their monopoly on legitimate history writing. Yet in parallel, the progressive vision of history as a global liberation struggle began to wane, yielding to a neoliberal belief in historically immutable economic laws. In this worldview, the past was domesticated. No longer a guiding star for action-be it in the form of an authoritative magistra vitae or a resource for subversive thinking about the future-the past has become a source of innocuous "heritage" defined by its role in the present. Emerging at the confluence of these tendencies, "memory laws are the most salient manifestations of this new form of historical consciousness: no single memory law actually bans any philosophy of history. They prohibit only misinterpretations of individual historical events that are regarded as sacred symbols of different "imagined communities'" (p. 49).

Following a first chapter that lays out the author's overall framework, Koposov details the evolution of memory laws in Western Europe: from early antifascist and antiracist legislation through the Holocaust denial laws passed in West Germany, Israel, and France to the internationalization of laws criminalizing Holocaust denial and, ultimately, the extension to other topics such as the Armenian genocide of 1915, colonialism, or the Spanish Civil War. Koposov also discusses counterarguments and resistance to memory laws, increasingly seen as assaults by politicians on the autonomy of historical debate. He ends the chapter with the observation that most "Holocaust denial laws" in fact omit the word "Holocaust," instead usually referring less specifically to the denial of Nazi crimes against humanity or, even more generally, the "denial of any genocide or other crimes against humanity" (pp. 124-125). Here Koposov accurately identifies a dilemma that remains unresolved in West European memory laws: while often aiming to outlaw denial of certain well-established facts, they typically refrain from identifying these facts directly, preferring to define them using generic formulas or references to the earlier verdicts of tribunals.

This observation is related to the other key distinction that underlies his comparative analysis: that between historical concepts that function like proper names, referencing specific individuals, collectivities, or events, and those that are used as general names, aspiring to universal validity. Every term in the continuum of historical concepts, Koposov argues, combines elements of both, but some are clearly closer to proper names and others to general names. His argument is that "the present-day politics of memory, especially in Russia, tends to privilege concepts that are closer to proper than to general names" (pp. 13-14). While the statement is meant to apply to memory laws in general, it becomes even more salient for Koposov the further east one moves across the continent. In the case of Eastern Europe, Koposov argues, there was an initial tension between a "pan-European" Holocaust memory and the "local" memory of Communism. This has not only resulted in multiple attempts to equate National Socialism and Communism, but has also meant that certain ways of universalizing the lessons of the Holocaust have not taken hold in the region: victims other than one's fellow nationals oppressed by Communism are rarely paid much attention to, and perpetrators are typically externalized. Thus, while many East European countries have passed Holocaust denial laws, they "were motivated by those countries' desire to join the European Union, rather than by their own legisla- 
tive tradition" (p. 152). Locally, de-Communization laws were more important: the 1998 Polish law, which criminalized Nazism and Communism equally, proved especially influential. Koposov reviews the many East European memory laws modeled on the Polish precedent as well as the less numerous ones inspired by the Gayssot Act or its later EU offshoots. He argues that the self-victimization tendencies were further amplified starting in 2004 by memory wars that he sees as resulting primarily from Russian President Vladimir Putin's neo-imperial ambitions.

I found the general/proper names distinction to be a useful heuristic device for thinking both about memory laws in general and about the variation among them. Still, given the importance of the distinction to Koposov's argument, I would have liked to see it more fleshed out. Problems of naming and reference have been a central concern in twentieth century philosophy, from Bertrand Russell (1905) to Jacques Derrida (1967) and Saul Kripke (1980), collectively casting doubt on the possibility of a linear distinction between specificity and universality in reference. Perhaps even more to the point, recent work in pragmatic sociology (which Koposov draws on in a different context) suggests that universalization or generalization can proceed along a number of different lines-on this view, using the law to endow symbols of the nation with general validity could be seen as one such mode, albeit one that is different from the civic universality implicit in more abstract formulations (Boltanski and Thévenot 1991; Thévenot 2014). This might help provide an even richer account of the two tendencies that Koposov diagnoses-the general rise of laws that appear to fall in the "proper names" category and the special prominence of the "proper names" logic in Russia.

The two long "regional chapters" are followed by a chapter that focuses specifically on Ukraine, due not only to the relevance of memory legislation to the ongoing crisis there, but also to the remarkable productivity with which Ukrainian lawmakers have engaged in drafting memory laws since the 2000s. One important observation from this chapter, among many others, is that pro-Russian Ukrainian politicians have been instrumental in drafting memory laws in neighboring Russia-a development that would have been difficult to anticipate in the years of presidents Leonid Kravchuk and Leonid Kuchma, who both pursued a remarkably agnostic or rather "multivector" (p. 181) politics of memory. Developments in Russia are then examined in two separate chapters, one covering competing projects to legislate about the past in the Boris Yeltsin years and one on the Putin era. This latter period has been marked by an increasing use of historical concepts of the "proper name" variety, among which Koposov mentions "sovereign democracy," a term that sounds abstract and universal but in fact simply refers to Russia qua Russia. Yet the main tendency Koposov identifies in the Putin era is a triumph of a certain myth of the Great Patriotic War, leading to legislative attempts to enshrine the war's official interpretation and defend it from criticism by referring to the Judgment of the Nuremburg Tribunal as a foundational document. As a result, laws such as the 2014 Law against the Rehabilitation of Nazism, also known as the Iarovaia Act, have been used to penalize even unexceptional statements such as the observation that World War II started with the German and Soviet invasion of Poland. 
This cursory review cannot do justice to the many merits of Koposov's book: steeped in the French tradition-Europe's richest- of debates about the relationship between history, memory, and the larger social sciences, his text also relies on a close reading of a formidable number of legislative texts. It draws on publications in most major European languages-a seemingly obvious requirement for historians of Europe but one that many fail to meet. Beyond the general arguments, the book offers a firework of original observations on almost every page.

Of course, a book of such scope is bound to invite some controversy. Some of my concerns are quibbles on matters of emphasis. In the section on the emergence of antifascist legislation, I was surprised not to find any discussion of Norbert Frei's (1996) detailed study of West Germany's early amnesty laws. Likewisegiven the centrality of references to Nuremberg, but also to the UN Genocide Convention, for the memory laws Koposov discusses-I missed engagement with research on the Soviet influence on the Nuremberg Trials (Hirsch 2008) or with work on how the United States was just as interested as the Soviet Union in restricting the scope of the UN Genocide Convention (Rabinbach 2005). Other points concern Koposov's methods: whereas most of his analysis is rooted in close readings of the sources, when it comes to Russian memory laws he occasionally engages in guesswork concerning the motivations of their authors and the involvement of the president. There are also more substantive points. In particular, much as I share Koposov's concern about the political instrumentalization of World War II memory in contemporary Russia, I find his depiction of that war memory to be overly black-and-white and rooted in liberal stereotypes that don't stand up to newer empirical research. I will mention just a few examples. The suppression of Holocaust memory in the Soviet Union and its satellite states was neither as systematic nor as top-down as previously thought and as Koposov would have us believe (Zeltser 2018). The statement that the poiskoviki search movement, which looks for unburied bodies of the war dead, has "degenerated in a routine exercise in 'patriotic education'" (p. 224) must strike anyone familiar with that movement as a gross exaggeration. Favorably comparing Viktor Suvorov's pop history books about the outbreak of the Second World War with US criticisms of the "good war" concept, as he does on page 218 , is problematic for a number of reasons-not least because one of the points of that criticism is to counter the US version of the kind of self-aggrandizing exceptionalism that Koposov rightly takes issue with in the Russian case (see, e.g., Williams 2018). In such passages Koposov's (perfectly understandable) personal investment in Russian debates about the politics of history shines through and tends to make his analysis less dispassionate than elsewhere in the book.

However, none of these criticisms should be taken to diminish the admirable achievement that this book represents, an achievement that should make it required reading for every Europeanist memory studies expert. In its sweeping scope and meticulous analysis, this may very well be the finest contribution yet by a Russiantrained scholar in the humanities to contemporary European history beyond Russian studies. 


\section{REFERENCES}

Boltanski, Luc, and Laurent Thévenot. 1991. De la justification: Les économies de la grandeur. Paris: Gallimard.

Derrida, Jacques. 1967. De la grammatologie. Paris: Éditions de Minuit.

Frei, Norbert. 1996. Vergangenheitspolitik: Die Anfänge der Bundesrepublik und die NS-Vergangenheit. Munich: Beck.

Hirsch, Francine. 2008. “The Soviets at Nuremberg: International Law, Propaganda, and the Making of the Postwar Order." American Historical Review 113(3):701-730.

Koposov, Nikolai. 2011. Pamiat' strogogo rezhima: Istoriia i politika v Rossii. Moscow: Novoe literaturnoe obozrenie.

Kripke, Saul A. 1980. Naming and Necessity. Cambridge, MA: Harvard University Press.

Rabinbach, Anson. 2005. "The Challenge of the Unprecedented: Raphael Lemkin and the Concept of Genocide." Jahrbuch des Simon-Dubnow-Instituts 4:397-420.

Russell, Bertrand. 1905. “On Denoting." Mind 14(4):479-493.

Thévenot, Laurent. 2014. "Voicing Concern and Difference: From Public Spaces to Common-Places." European Journal of Cultural and Political Sociology 1(1):7-34.

Williams, Bruce A. 2018. "The Story of the 'Good War' Must Change: Seeing WWII as an American Triumph Prevents Understanding Russia and Europe Today." Public Seminar, August 9. http:// www.publicseminar.org/2018/08/the-story-of-the-good-warmust-change.

Zeltser, Arkadi. 2018. Unwelcome Memory: Holocaust Monuments in the Soviet Union. Translated by A. S. Brown. Jerusalem: Yad Vashem Publications. 